\title{
Population structure of Geodorum densiflorum (Orchidaceae) in relation to habitat disturbance and vegetation characteristics
}

\author{
SITI NURFADILAH" \\ Purwodadi Botanic Gardens, Research Centre for Plant Conservation and Botanic Gardens, Indonesian Institute of Sciences. Jl. Surabaya-Malang Km. 65 \\ Purwodadi, Pasuruan 67163, East Java, Indonesia. Tel./fax.: +62-341-426046, `email: siti.nurfadilah@lipi.go.id; fadilahzr@ gmail.com
}

Manuscript received: 15 January 2020. Revision accepted: 12 March 2020.

\begin{abstract}
Nurfadilah S. 2020. Population structure of Geodorum densiflorum (Orchidaceae) in relation to habitat disturbance and vegetation characteristics. Biodiversitas 21: 1422-1431. Habitat disturbance can have large impacts on the persistence, survival, and growth of plant populations, particularly for orchids, one of the most threatened plant families. The present study aimed to investigate the impact of habitat disturbance on the population of a terrestrial orchid, Geodorum densiflorum (Lam.) Schltr, in terms of its population structure which is important in determining population viability for the species survival. The species occurred in three habitat types (disturbed habitat i.e. totally converted habitat into cananga plantation, burnt habitat, and undisturbed habitat). Plots of $2 \mathrm{~m} \times 2 \mathrm{~m}$ were established in these three habitat types and the population structure of $G$. densiflorum in these three habitat types was analyzed. After analysis, three population types could be distinguished (i) 'regressive population' in disturbed habitat characterized by the absence of seedlings and dominated by generative adults, (ii) 'dynamic population' in burnt habitat characterized by a large proportion of young individuals (seedlings and juveniles) relative to the adults, and (iii) 'normal population' in undisturbed habitat characterized by the prevalence of adults but a small proportion of young individuals. The variation in the population structure of G. densiflorum appears to be related to the difference in vegetation characteristics of the three habitat types. The absence of seedlings of $G$. densiflorum in disturbed habitat was related to the grasses dominating vegetation that could inhibit seedling recruitment of G. densiflorum. Grasses were absent and hardly occurred in burnt habitat and undisturbed habitat allowing seedling recruitments of $G$. densiflorum in these habitat types. The highest seedling proportion and density of $G$. densiflorum were observed in burnt habitat as burning can remove aboveground biomass and reduce competition with surrounding vegetation providing safe microsites for seedling establishment and recruitment. The present study has implication in the orchid conservation and provide recommendation for the orchid conservation (i) to avoid totally converted habitat as it had consequences on the absence of seedling recruitment (ii) to perform mowing and managed burning to increase seedling recruitment of $G$. densiflorum which is important for population enlargement, persistence, and survival.
\end{abstract}

Keywords: Burnt habitat, disturbed habitat, Geodorum densiflorum, population structure undisturbed habitat

\section{INTRODUCTION}

Habitat disturbance is widely recognized to have large impacts on the persistence, survival, and growth of plant population, particularly for orchids, one of the most threatened plant families (Coates et al. 2006; Gale et al. 2018; IUCN 1996). Variation in degree of habitat disturbance can have different impacts on the orchid population. A large scale of habitat disturbance resulting in severe deterioration of orchid habitat, such as land clearing, deforestation, and land-use change has been shown to cause population decline and disappearance of many orchid species (IUCN 1996; Jacquemyn et al. 2005; Kull and Hutchings 2006; Nicole et al. 2005; Vogt-Schilb et al. 2015). Severe destruction on orchid natural habitats because of land clearing is known to have consequences on the environmental alteration and vegetation composition change as a result of treeless environment, with the vegetation composition, is commonly dominated by grasses that could inhibit seedling development, emergence, and recruitments influencing the survival of orchid population (Akhalkatsi et al. 2014; Comita et al. 2009; Jacquemyn et al. 2007; Wotavova et al. 2004). In contrast, a small scale of habitat disturbance such as mowing and fire removing underground plant biomass and reducing competition from dominant grasses can increase population size of orchids as this disturbance provides safe microsites for orchid seedling establishment and recruitment (Coates et al. 2006; Jersakova and Malinova 2007; Rasmussen et al. 2015; Sletvold et al. 2010).

Understanding population structure of orchids in these various degrees of habitat disturbance is important to increase understanding of orchid population viability to support management of orchid conservation as it can give insights on (i) the demography, composition, and proportion of history life stages of orchids (seedlings, juveniles, vegetative adults and generative adults) (Cleavitt et al. 2016; Nurfadilah 2017; Sletvold et al. 2010) in relation to habitat disturbance and (ii) the critical stages of the orchid life cycle; to formulate prescription for conservation of threatened populations for the persistence and survival of the orchids. Assessment of population structure for conservation purposes has been applied to some other species from other plant families, including Primula elatior (Primulaceae), Geum urbanum (Rosaceae) Arum maculatum, (Araceae), Gentiana pneumonanthe (Gentianaceae), and Salvia pratensis (Lamiaceae). This assessment has been success to assess the population 
viability and provide recommendations for the effective conservation of these species (Endels et al. 2004; Hegland et al. 2001; Oostermeijer et al. 1994).

Population viability can be assessed through detailed demographic studies, however, these methods is considered less efficient as it is laborious and take many years to complete and hampering their wide use in conservation biology (Harvey 1985; Hegland et al. 2001; Oostermeijer et al. 1994). Assessment of population viability through studies of population structure is seen to be more efficient to assess population viability as it is relatively simple and less time-consuming. Population structure has been determined based on the proportion and density of different history life stages (seedlings, juveniles, vegetative adults, and generative adults) in the population (Endels et al. 2004; Jacquemyn et al. 2003; Hegland et al. 2001; Oostermeijer et al. 1994). What history life stages dominating or critical in the population can be seen from the proportion and density of each history life stage in the population that is useful to formulate prescription for the viability of populations.

There were three population types that have been recognized based on the analysis of population structure, namely (i) 'Regressive population' characterized by the absence or low density of young individuals and dominated by generative adults, (ii) 'dynamic population' characterized by a large proportion of young individuals (seedlings and juveniles) relative to the adults, and (iii) 'normal population' characterized by the prevalence of adults but a small proportion of young individuals (Endels et al. 2004; Hegland et al. 2001; Oostermeijer et al. 1994). The most important descriptor for each population type is the relative proportion of young individuals (seedlings and juveniles). Of these three population types, dynamic population with a high proportion of young individuals indicating the high rate of seedling recruitment and rejuvenation, is seen as an important type for the population enlargement, sustainability and viability (Hegland et al. 2001; Oostermeijer et al. 1994; Rasmussen et al. 2015). Seedling recruitment is a fundamental component and an important process affecting the population structure, dynamics and growth of orchids (Jacquemyn et al. 2007; Jersakova and Malinova 2007; Rasmussen et al. 2015).

The present study aimed to investigate (i) the population structure and population types of a terrestrial orchid, Geodorum densiflorum (Lam.) Schltr. that occurred in three habitat types linked to habitat disturbance (a) disturbed habitat (totally converted habitat into cananga plantation;(b) burnt habitat experiencing a small scale of habitat disturbance by partially anthropogenic fire (burning) and (c) undisturbed habitat); (ii) the relationship between proportion and density of life stages (young stages and adult stages) and environmental factors across the three habitat types, (iii) relationship between population structure and vegetation characteristics across the three habitat types. The present study has implications for orchid conservation to support management of orchid conservation for the persistence and survival of orchid population.

\section{MATERIALS AND METHODS}

\section{Study area}

Populations of Geodorum densiflorum in the present study were located in Purwodadi District, Pasuruan Regency, East Java, Indonesia (Figure 1). The populations occurred in three habitat types (disturbed habitat, burnt habitat, and undisturbed habitats) located in Cananga plantation, Capang woodland, and Gajahrejo woodland, respectively (Figure 2). Cananga plantation was categorized as disturbed habitat, which was totally converted into cananga plantation. It had habitat characteristics open canopy cover, more light access, and underground vegetation was dominated by grasses. Capang woodland was categorized as burnt habitats that experienced partially traditional anthropogenic burning, with semi-open canopy cover, and the absence of grasses in the composition of underground vegetation. Gajahrejo woodland was categorized as undisturbed habitats, characterized by many trees providing shady area and grasses hardly occurred in the composition of underground cover (Table 1).

\section{Study species}

Geodorum densiflorum is a terrestrial orchid with short underground stems and pseudobulbs. Inflorescences arising from different parts of the pseudobulbs, held above the leaves about $40 \mathrm{~cm}$ long, near the apex with short rachis bearing many-flowers leading to the rachis points downwards. The flowers are white or pink with purple stripes on the labellum (Comber 1990, Lin 2012). Geodorum densiflorum can be autonomously self-pollinate. The flowers were also visited by Andrenidae species and Ceratina cognata that might facilitate pollination (Lin, 2012). The species has a wide range of distribution from Andaman island, Assam, throughout South East Asia and eastwards to Australia, and some of Pacific islands (Comber 1990, WCSP 2017)

Table 1. Description of three habitat types of Geodorum densiflorum

\begin{tabular}{lll}
\hline Habitats of Geodorum densiflorum & Classifications of habitats & Description \\
\hline Cananga plantation & Disturbed habitat & Totally converted habitat into cananga plantation \\
Capang woodland & Burnt habitat & Habitat experienced partially traditional anthropogenic fire \\
Gajahrejo woodland & Undisturbed habitat & Undisturbed habitat \\
\hline
\end{tabular}




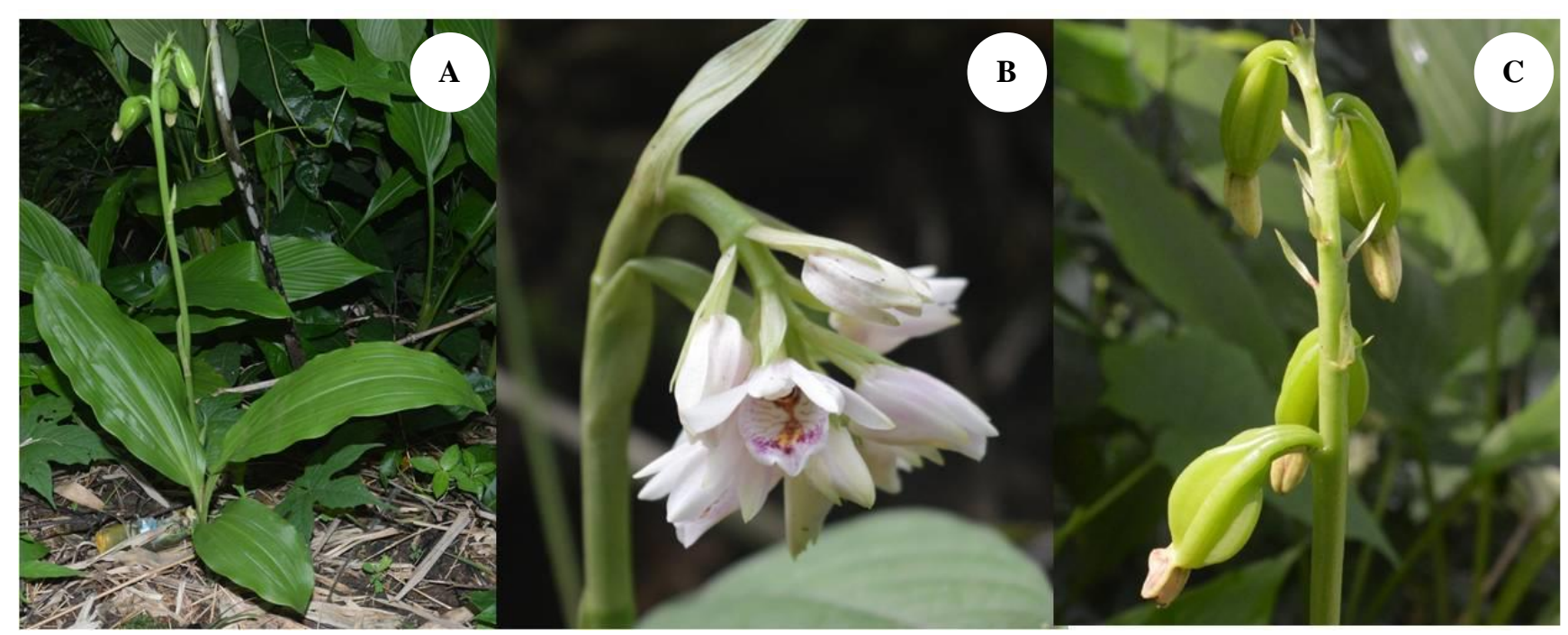

Figure 1. Geodorum densiflorum, a terrestrial orchid. The plant of G. densiflorum (A). The flowers of G. densiflorum (B). The fruits of G. densiflorum

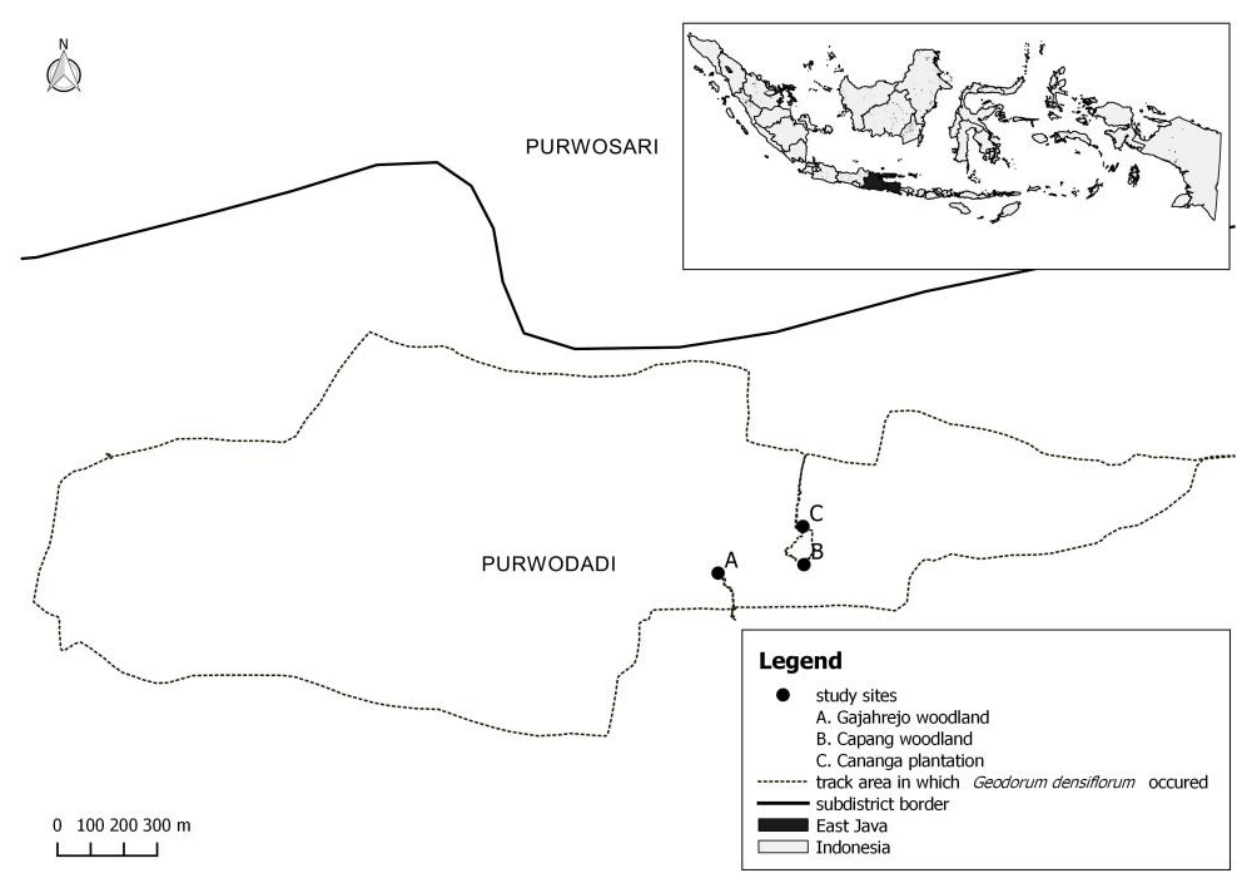

Figure 2. Map of area of populations of G. densiflorum in three habitat types in Purwodadi District, Pasuruan Regency, East Java, Indonesia

\section{Procedures}

Determination of history life stages, environment assessment and vegetation analysis

Plots of $2 \mathrm{~m} \times 2 \mathrm{~m}$ were established across the three types of habitats of $G$. densiflorum (disturbed habitat (10 plots), burnt habitat (5 plots), and undisturbed habitats (34 plots)). Number of individuals of $G$. densiflorum in each plot was counted. In each plot, plant height, leaf length, and width of each individual of $G$. densiflorum were measured. Population structure was assessed based on the proportion and density of four history life stages of $G$. densiflorum (seedlings, juveniles, vegetative adults, and generative adults).
The determination and classification of the history life stages of $G$. densiflorum were based on the leaf area; seedlings $\left(<50 \mathrm{~cm}^{2}\right)$; juveniles $\left(50-100 \mathrm{~cm}^{2}\right)$, vegetative adults ( $>100 \mathrm{~cm}^{2}$ without flowers), and generative adults (> $100 \mathrm{~cm}^{2}$ with flowers or fruits). Leaf area was estimated by calculating leaf length and width in an elliptic area $=\pi X^{1 / 2}$ leaf length $x$ 1/2 leaf width) (Cleavitt et al. 2016).

Assessment of environmental factors including canopy closure, density of grasses, litter cover, and soil $\mathrm{pH}$, as well as vegetation characteristics were performed in each habitat type. Canopy closure, density of grasses, litter cover, and soil $\mathrm{pH}$ were measured in each plot. 
Vegetation characteristics were assessed by identifying plant species surrounding $G$. densiflorum and number of individuals of each species was recorded in each plot. Composition of surrounding vegetation in each habitat type was also assessed using parameters including Important Value Index, Density (D), Relative Density (RD), Frequency (F), and Relative Frequency (RF). Similarity and dissimilarity of species composition of surrounding vegetation between the three habitat types were analyzed using Indices of Similarity of Jaccard and Sorensen.

\section{Data analysis}

Data of proportion and density of history life stages in plots in burnt habitat were pooled to fit the graph of the means of proportion and density of history life stages across plots in burnt habitat. Data of proportion and density of history life stages in plots in the other two habitat types (disturbed and undisturbed habitats) were not pooled as they fit the graph of the means of proportion and density of history life stages across plots of disturbed and undisturbed habitats, respectively.

Density and proportion of seedlings, juveniles, vegetative adults, and generative adults of the three habitat types were analyzed using one way ANOVA. Canopy closure, litter cover, and soil $\mathrm{pH}$ of the three habitat types were also analyzed using one way ANOVA. Relationship between density and proportion of young stages (seedlings + juveniles); adult stages (vegetative adults + generative adults) and environmental factors were analyzed using Regression. All analyses were performed using MINITAB 14.0.

Rejuvenation in each habitat type was also assessed to investigate the recruitments and growth of young individuals based on the sum of density of seedlings and juveniles relative to the sum of generative adults) (Endels et al. 2004).

Rejuvenation $=\underline{\mathrm{S}+\mathrm{J}}$

Where:

$S$ : density of seedlings

$\mathrm{J}$ : density of juveniles

$\mathrm{G}$ : density of generative adults

Relationship between population structure of $G$. densiflorum and the vegetation characteristics surrounding the orchid was assessed through relationship between the ratio of density of young stages (seedlings and juveniles) and density of adult stages (vegetative adults and generative adults) of $G$. densiflorum and characteristics of the vegetation surrounding $G$. densiflorum in the three habitat types. CANOCO with direct redundancy analysis of RDA was used. Direct gradient analysis is a method to find the directions of variability in vegetation community data, which correlate with the ratio of density of young stages and adult stages of $G$. densiflorum in each habitat in the present study.

Furthermore, vegetation characteristics were also analyzed based on the vegetation composition that was assessed based on relative density (RD), relative frequency (RF) and Important Value Index (IVI).

$$
\begin{aligned}
& \mathrm{RD}=\frac{\text { Number of individuals of a taxon }}{\text { Total number of individuals }} \times 100 \\
& \mathrm{RF}=\frac{\text { Number of plots containing a taxon }}{\text { Total frequencies of all taxa }} \times 100
\end{aligned}
$$

IVI = RD + RF (Kusmana 1995; Sutomo et al. 2015)

To compare species composition between habitat types, similarity and dissimilarity of underground vegetation composition between habitat types were analyzed using Jaccard Index and Sorensen Index based on the presence and absence of species.

$$
\begin{aligned}
& \text { ISJ }=a / a+b+c \\
& \text { ISS }=2 a / 2 a+b+c
\end{aligned}
$$

Where:

ISJ : Index of Similarity of Jaccard

ISS : Index of Similarity of Sorensen

a: number of species in common between habitat types

b: number of species unique to the first habitat types

c: number of species unique to the second habitat types

\section{RESULTS AND DISCUSSION}

\section{Population structure and population types}

Population structure in disturbed habitat was characterized by the absence of seedlings, a small proportion of juveniles, and a relatively large proportion and high density of adults, especially generative adults (Figures 3 and 4). This population type was characterized by zero rejuvenation $(S+J) / G$ ratio $=0$ (Table 2$)$. This population structure can be classified as 'regressive population'.

Population structure in burnt habitat had a relatively high proportion and large density of young individuals (seedlings and juveniles) and relatively low proportion and density of adults (Figures 3 and 4). This population type had a relatively high rejuvenation $(\mathrm{S}+\mathrm{J}) / \mathrm{G}$ ratio with a mean of 5.70 (Table 2). This population type can be classified as 'dynamic population'.

In undisturbed habitat, the population structure was characterised by a high proportion and density of adults and relatively low proportion and density of young individuals (seedlings and juveniles) (Figure 3 and 4). This population type had a mean of rejuvenation $(\mathrm{S}+\mathrm{J}) / \mathrm{G}$ ratio 0.16 (Table 2). This population type can be classified as 'normal population'.

The three population types had a significantly different rejuvenation $(\mathrm{S}+\mathrm{J}) / \mathrm{G}$ ratio $(\mathrm{ANOVA}, \mathrm{df}=2, \mathrm{P}=0.000$ ), proportion of young stages (the sum of proportion of seedlings and juveniles) (ANOVA d.f. $=2, P=0.034$ ), and density of young stages (ANOVA d.f. $=2, P=0.000$ ). The proportion of young stages in disturbed habitat was 0.233; in burnt habitat was 0.73 and in undisturbed habitat was 0.26 . The density of young stages in disturbed habitat was $0.1 \mathrm{~m}^{-2}$, in burnt habitat was $1.9 \mathrm{~m}^{-2}$ and in undisturbed habitat was $0.17 \mathrm{~m}^{-2}$ Total plant density between habitat 


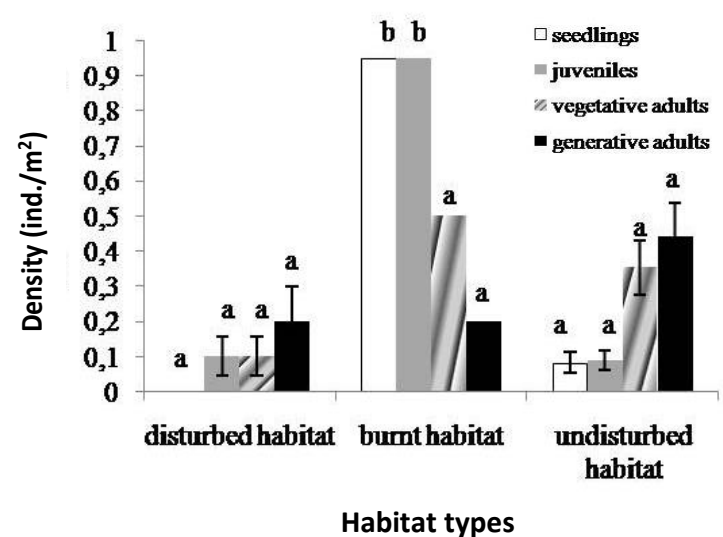

Figure 3. Density of history life stages of Geodorum densiflorum (means) in three habitat types (disturbed habitat, burnt habitat, and undisturbed habitat). Different letters above column indicate significantly different $(\mathrm{P}<0.05)$, while same letters above column indicate not significantly different $(\mathrm{P}>0.05)$

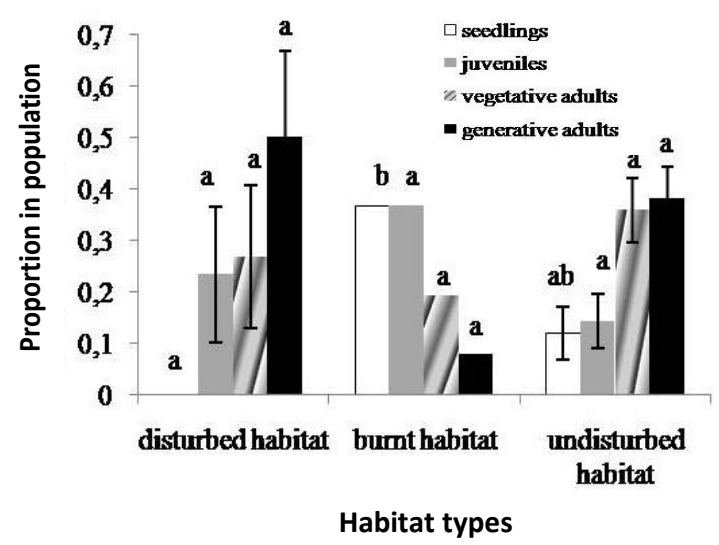

Figure 4. Proportion of history life stages of Geodorum densiflorum (means) in three habitat types (disturbed habitat, burnt habitat, and undisturbed habitat). Different letters above column indicate significantly different $(P<0.05)$, while same letters above column indicate not significantly different $(\mathrm{P}>0.05)$

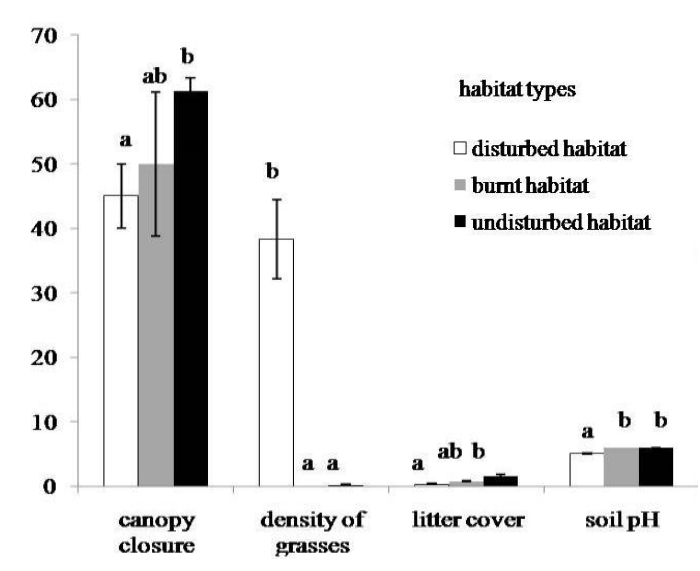

Figure 5. Environmental factors in three habitat types of Geodorum densiflorum (means) (disturbed habitat, burnt habitat, and undisturbed habitat). Different letters above column indicate significantly different $(\mathrm{P}<0.05)$, while same letters above column indicate not significantly different $(\mathrm{P}>0.05)$. types was also distinctly different. Total plant density ranged from $0.4 \mathrm{~m}^{-2}$ in disturbed habitat, through 2.6 plants $\mathrm{m}^{-2}$ in burnt habitat, to 0.963 plants $\mathrm{m}^{-2}$ in undisturbed habitat (ANOVA, d.f. $=2, P=0.000$ ) (Table 2).

\section{Relationship between proportion and density of life stages and environmental factors}

Environmental factors across three habitat types of $G$. densiflorum were significantly different. Canopy closure, litter cover, and soil $\mathrm{pH}$ in disturbed habitat was the lowest compared to those in burnt habitat and undisturbed habitat. However, density of grasses in disturbed habitat was the highest compared to that in burnt habitat and undisturbed habitat (Figure 5).

Multiple regression analysis with environmental factors (canopy closure, density of grasses, litter cover and soil $\mathrm{pH})$ as independent variables and density and proportion of life stages (young stages and adult stages) as dependent variables yielded some significant correlation (Table 3). There were negative correlations between canopy closure and density of young stage, density of grasses and adult stage, vegetative adult, and total density. In addition, there was negative marginally significant correlation between proportion of vegetative adults and density of grasses (Table 3).

\section{Relationship between population structure and vegetation characteristics}

Results of RDA analysis have shown that grasses (including Axonopus compressus, Oplismenus burmanni, and Oplismenus compositus) are concentrated at disturbed habitats that had 'regressive population' (young stages hardly occurred, seedlings were absence, and dominated by adults). In burnt habitat that had 'dynamic population' characterized by the highest proportion of young stages (seedlings and juveniles), grasses were absent. Furthermore, vegetation composition in undisturbed habitat was dominated by non-grasses vegetation (Figure 6).

Analysis of vegetation composition in three types of habitats also revealed variation in the underground vegetation composition and confirmed that grasses including Axonopus compressus, Oplismenus burmanni, and Oplismenus compositus dominating disturbed habitat that had 'regressive population', while burnt habitat and undisturbed habitat were dominated by non-grasses vegetation (Figures 7, 8, and 9). The most important species in disturbed habitat were grasses including Oplismenus burmanni that had the highest density, followed by Oplismenus compositus, and Axonopus compressus (Figure 7). The most important species in burnt habitat was non-grasses vegetation including Curcuma sp, followed by Boesenbergia rotunda, and Peperomia pellucida (Figure 8). Vegetation composition in undisturbed habitat was also dominated by non-grasses vegetation including Globba marantina and Peperomia pellucida (Figure 9). 
Table 2. Rejuvenation, proportion, and density of young stages (seedlings + juveniles) and adult stages (vegetative adults and generative adults), and total density (seedlings + juveniles + vegetative adults + generative adults) of Geodorum densiflorum in three habitat types. Different letters in parenthesis indicate significantly different. $(\mathrm{P}<0.05)$, while same letters in parenthesis indicate not significantly different $(\mathrm{P}>0.05) . \mathrm{SE}=$ Standard Error.

\begin{tabular}{lllcccc}
\hline Habitat types & $\begin{array}{c}\text { Rejuvenation } \\
( \pm \mathbf{S E})\end{array}$ & $\begin{array}{c}\text { Proportion of } \\
\text { young stages } \\
( \pm \mathbf{S E})\end{array}$ & $\begin{array}{c}\text { Proportion of } \\
\text { adult stages } \\
( \pm \mathbf{S E})\end{array}$ & $\begin{array}{c}\text { Density of } \\
\text { young stages } \\
( \pm \mathbf{S E})\end{array}$ & $\begin{array}{c}\text { Density of } \\
\text { adult stages } \\
( \pm \mathbf{S E})\end{array}$ & $\begin{array}{c}\text { Total density } \\
( \pm \mathbf{S E})\end{array}$ \\
\hline Disturbed habitat & $0.00 \pm 0.00 \mathrm{a}$ & $0.233 \pm 0.13 \mathrm{a}$ & $0.767 \pm 0.132 \mathrm{~b}$ & $0.1 \pm 0.055 \mathrm{a}$ & $0.3 \pm 0.09 \mathrm{a}$ & $0.4 \pm 0.08 \mathrm{a}$ \\
Burnt habitat & $5.7 \pm 0.00 \mathrm{~b}$ & $0.73 \pm 0.00 \mathrm{~b}$ & $0.27 \pm 0.000 \mathrm{a}$ & $1.9 \pm 0.00 \mathrm{~b}$ & $0.7 \pm 0.00 \mathrm{a}$ & $2.6 \pm 0.00 \mathrm{~b}$ \\
Undisturbed habitat & $0.16 \pm 0.056 \mathrm{a}$ & $0.26 \pm 0.066 \mathrm{a}$ & $0.74 \pm 0.066 \mathrm{~b}$ & $0.17 \pm 0.039 \mathrm{a}$ & $0.79 \pm 0.158 \mathrm{a}$ & $0.963 \pm 0.17 \mathrm{a}$ \\
\hline
\end{tabular}

Table 3. Statistics of the multiple regression models with the proportion and density of young stages (seedlings and juveniles) and adult stages (vegetative adults and generative adults) as dependent, and the vegetation structure parameters as independent variables. The lefthand side gives the standardized regression coefficients $(\beta)$ and the t-test for their deviation from zero. The right-hand side gives the ANOVA table for the multiple regression model. The results are shown only for significant models.

\begin{tabular}{|c|c|c|c|c|c|c|c|c|}
\hline \multirow{2}{*}{\multicolumn{2}{|c|}{$\beta$}} & \multirow[b]{2}{*}{$\mathbf{T}$} & \multirow[b]{2}{*}{$\mathbf{P}$} & \multicolumn{5}{|c|}{ Analysis of variance } \\
\hline & & & & Source & d.f & MS & F-ratio & $\mathbf{P}$ \\
\hline \multicolumn{9}{|c|}{ Young stage density $R^{2}=0.079(\log$ transformed $)$} \\
\hline Constant & 0.1458 & 0.98 & 0.333 & Regression & 1 & 0.30532 & \multirow[t]{2}{*}{4.03} & \multirow[t]{2}{*}{0.050} \\
\hline Canopy closure & -0.005074 & -2.01 & 0.050 & Residual & 47 & 0.07573 & & \\
\hline \multicolumn{9}{|c|}{ Adult stage density $R^{2}=0.088$ (log transformed) } \\
\hline Constant & -0.14842 & -3.10 & 0.003 & Regression & 1 & 0.43138 & \multirow[t]{2}{*}{4.63} & \multirow[t]{2}{*}{0.037} \\
\hline Density of grasses & -0.005361 & -2.15 & 0.037 & Residual & 47 & 0.09319 & & \\
\hline \multicolumn{9}{|c|}{ Vegetative adult density $R^{2}=0.096$ (not transformed) } \\
\hline Constant & 0.37232 & 6.11 & 0.000 & Regression & 1 & 0.7495 & \multirow[t]{2}{*}{4.96} & \multirow[t]{2}{*}{0.031} \\
\hline Density of grasses & -0.007066 & -2.23 & 0.031 & Residual & 47 & 0.1510 & & \\
\hline \multicolumn{9}{|c|}{ Total density $R^{2}=0.088$ (not transformed) } \\
\hline Constant & 1.1452 & 7.44 & 0.000 & Regression & 1 & 4.0320 & \multirow[t]{2}{*}{4.18} & \multirow[t]{2}{*}{0.046} \\
\hline Density of grasses & -0.01639 & -2.04 & 0.046 & Residual & 47 & 0.9642 & & \\
\hline \multicolumn{9}{|c|}{ Vegetative adult proportion $R^{2}=0.068$ (arcsin transformed) } \\
\hline Constant & 0.60069 & 6.96 & 0.000 & Regression & 1 & 1.0332 & \multirow[t]{2}{*}{3.41} & \multirow[t]{2}{*}{0.071} \\
\hline Density of grasses & -0.008297 & -1.85 & 0.071 & Residual & 47 & 0.3033 & & \\
\hline
\end{tabular}

Note: df: degrees of freedom; MS: mean square; F: variance ratio, P: denotes significance

Table 4. Similarity and dissimilarity of underground vegetation species among G. densiflorum habitat types (Jaccard and Sorensen Index)

\begin{tabular}{lcccc}
\hline \multirow{2}{*}{ Comparison between habitats } & \multicolumn{2}{c}{ \% similarity } & \multicolumn{2}{c}{ \% dissimilarity } \\
& Jaccard Index & $\begin{array}{c}\text { Sorensen } \\
\text { Index }\end{array}$ & \multirow{2}{*}{ Jaccard Index } & Sorensen Index \\
\hline Disturbed habitat-burnt habitat & 22.73 & 37.04 & 77.27 & 62.96 \\
Disturbed habitat-undisturbed habitat & 21.15 & 34.92 & 78.85 & 65.08 \\
Burnt habitat-undisturbed habitat & 19 & 31.93 & 81 & 68.07 \\
\hline
\end{tabular}

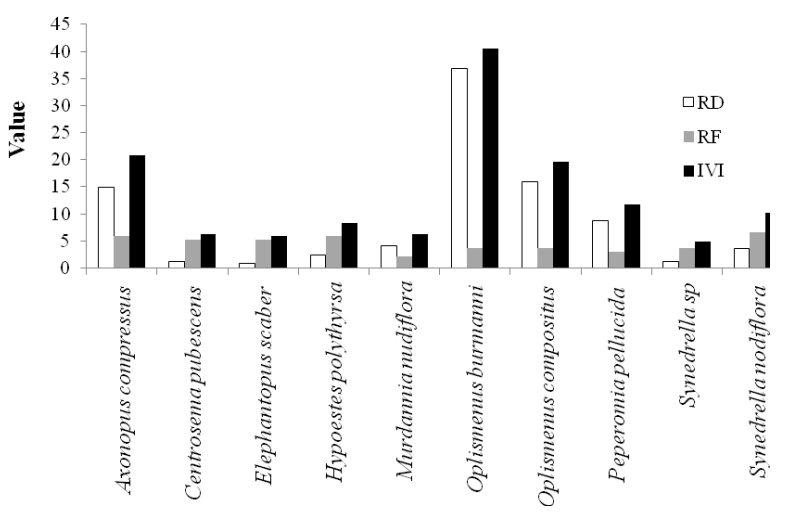

Figure 7. The most ten highest important species in underground vegetation surrounding Geodorum densiflorum in disturbed habitat. RD: Relative Density; RF: Relative Frequency; IVI: Important Value Index

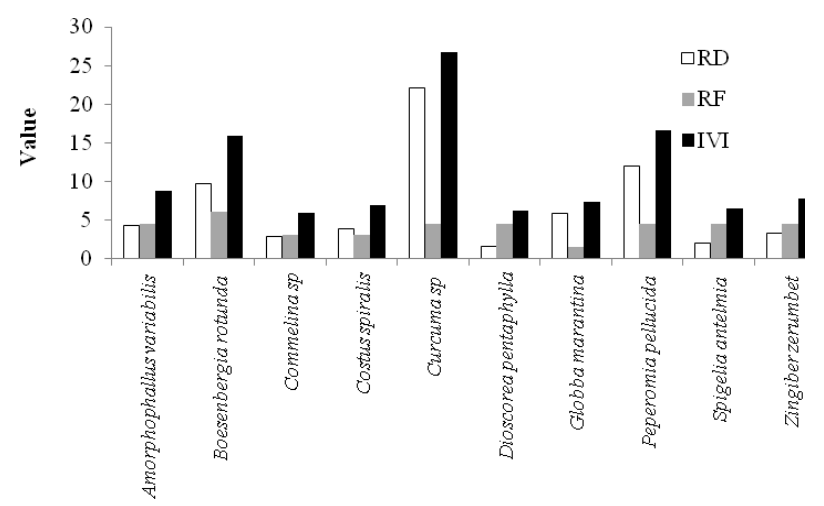

Figure 8. The most ten highest important species in underground vegetation surrounding Geodorum densiflorum in burnt habitat. RD: Relative Density; RF: Relative Frequency; IVI: Important Value Index 


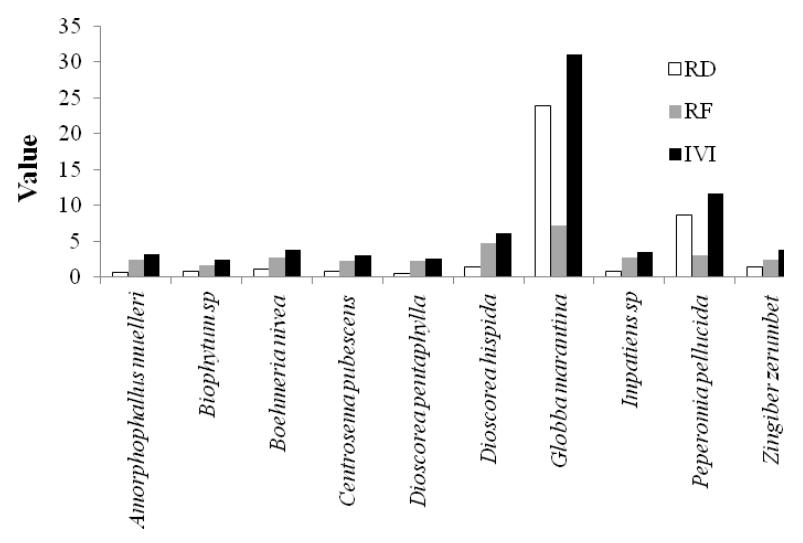

Figure 9. The most ten highest important species in underground vegetation surrounding Geodorum densiflorum in undisturbed habitat. RD: Relative Density; RF: Relative Frequency; IVI: Important Value Index

Characteristics of vegetation surrounding $G$. densiflorum in the three habitat types were also analyzed using analysis of similarity and dissimilarity of species composition of underground vegetation among habitat types using Jaccard and Sorensen indices (Table 4). The similarity of species composing underground vegetation among habitat types ranged from $19 \%$ to $22.73 \%$ (Jaccard Index) and ranged from $31.93 \%$ to $37.04 \%$ (Sorensen Index). The results indicate a high dissimilarity of species composition between habitat types confirming that each habitat type has a specific vegetation characteristic that was distinct from each other.

\section{Discussion}

The present study has shown the population structure of $G$. densiflorum that can be classified into 3 population types (regressive, dynamic, and normal population). These three population types also have been reported by other studies on the population structure of other species, such as Primula elatior, Geum urbanum, and Arum maculatum, Gentiana pneumonanthe, and Salvia pratensis (Endels et al. 2004; Hegland et al. 2001; Oostermeijer et al. 1994).

From the results of analysis of environmental factors and vegetation composition, the distinct difference of population structure of $G$. densiflorum in the three habitat types was related to environmental factors and vegetation composition. In particular, the density of grasses and canopy closure had a significant effect on the density and proportion of the different life states in $G$. densiflorum population. 'Regressive population' characterized by the absence of seedlings was observed in disturbed habitat, with more open canopy closure as a result of treeless environment. The consequence of more open canopy closure in disturbed habitats was the dominance of grasses that could inhibit seed germination and seedling recruitments resulting in the absence of seedlings of $G$. densiflorum in disturbed habitat. Grasses are widely recognized to inhibit orchid seedling recruitments as they can overgrow the orchid. In the present study, density of grasses was also negatively correlated with young stage and adult stage density, vegetative adult density, and total density of $G$. densiflorum indicating that grasses are potential to inhibit orchids throughout the orchid life cycle. Other studies also reported that grasses had negative effects on the populations of orchids, such as Peristylus goodyeroides (Nurfadilah 2017) and Dactylorhiza majalis (Wotavova et al. 2004).

'Dynamic population' characterized by a high proportion and density of young stages (seedlings and juveniles) was observed in burnt habitat. Burnt habitat had experience anthropogenic fire which has important roles in the removal of above-ground biomass and competitive surrounding vegetation providing safe sites for orchid seed germination and seedling development. Burning and fire are well known to increase orchid seedling recruitment which is important for the population enlargement. Other studies also reported the importance of managed burning for seedling recruitment of orchids, such as Prasophyllum (Coates et al. 2006) and for the increase of flowering and vigor of another orchid Diuris punctata Sm. var. punctata (Lunt 1994).

In undisturbed habitat and unmanaged habitat, the established adult individuals would grow normally without disturbance leading to the high proportion and density of adult stages in the population. Low numbers of seedlings emerged on the few, scattered microsites suitable for germination and seedling recruitment. In this way, 'normal' populations were formed in which adult individuals predominated, but seedlings and juveniles were also present at low densities.

The close relationship between population structure of G. densiflorum and vegetation characteristics in habitats linked to habitat disturbance has implications on the conservation of the species. The present study has demonstrated that disturbed habitat; orchid habitat which is totally converted into plantation and dominated by grasses has to lead to the absence of seedlings that would have consequences on the slow growth of population and the population would probably decline because there is no seedling recruitment. Density of grasses also had negative effects on the proportion of vegetative adults and density of adult stages as grasses overgrow the adult orchids. This will have consequences on the population decline and disappearance of the orchids.

The dominance of grasses in disturbed habitat in the present study correspond with other studies demonstrating that forest clear-cutting had lead to the open canopy cover that could change understorey light conditions and alter vegetation composition which is dominated by grasses and herbs and orchids hardly occurred in this habitat (Akhalkatsi et al. 2014; Comita et al. 2009). Furthermore, Wotavova et al. (2004) also reported that the absence of orchids in their natural habitats was related to the prevalence of grasses.

Therefore, it is suggested to avoid totally habitat conversion of the orchids as it will threaten the orchid population leading to the population decline and disappearance of the orchids. Recommendation for conservation of $G$. densiflorum in disturbed habitat dominated by grasses is by mowing to remove grasses from underground cover to allow seedling establishment and 
recruitment. Mowing is common management practice to remove competing for vegetation surrounding orchids to increase population viability of the orchids (Janec ${ }^{2}$ kova et al. 2006; Kull and Hutchings 2006; Sletvold et al. 2010; Wotavova et al. 2004).

Dynamic population with the highest proportion and density of young stages (seedlings and juveniles) that belong to burnt habitats indicates that burning is favorable for seedling recruitments which is important for population enlargement. The 'dynamic population' type is important for the viability and survival of orchid populations. Therefore, managed burning is recommended to provide safe sites for seedling recruitments for the population enlargement. Many studies also have recommended managed burning in the habitats of some other orchid species, such as Prasophyllum correctum and Diuris punctata Sm. var.punctata (Coates et al. 2006; Lunt 1994). It is a general observation for terrestrial orchid species that seedling establishment took place after natural or anthropogenic disturbance of a dense vegetation cover by fires, mowing, and other small-scale disturbance (Janec'kova' et al. 2006; Rasmussen et al. 2015; Whigham and Willems 2003).

The present study has revealed the population structure of $G$. densiflorum providing a basis for the assessment of population viability which is important for the survival of population of the species as well as recommendation to support the population viability of the orchid through (i) mowing to remove grasses from the underground cover to allow seedling establishment and recruitment (ii) managed burning to provide safe sites for seed germination and seedling development.

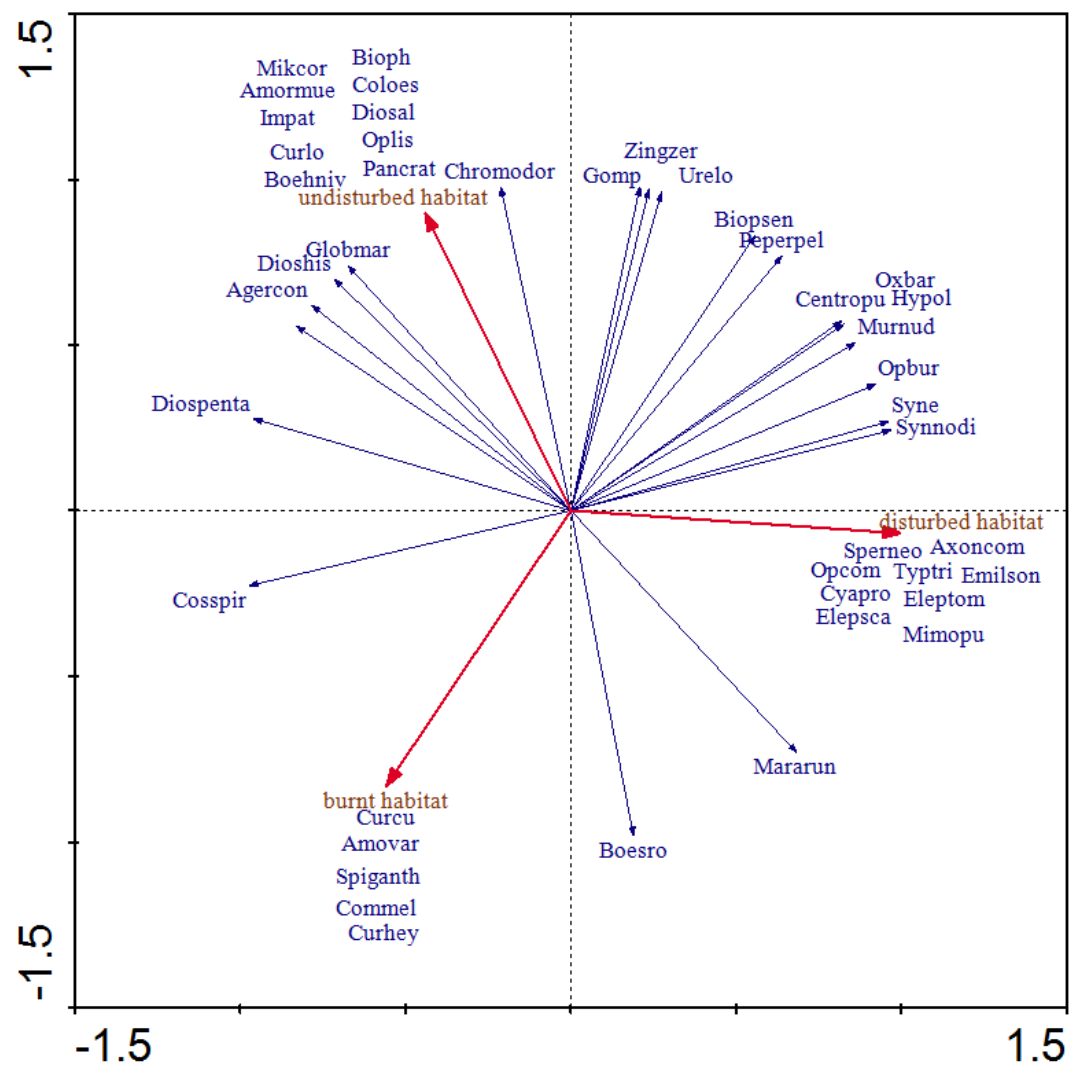

Figure 6. Results of RDA of three types of habitats of $G$. densiflorum. Legend: disturbed habitat had a low ratio of density of young stages and density of adult stages (0.05), burnt habitat had the highest ratio of density of young stages and density of adult stages (2.71), undisturbed habitat (Gajahrejo) had ratio of density of young stages and density of adult stages (0.15). Agercon (Ageratum conyzoides (L.) L.); Amormue (Amorphophallus muelleri Blume); Amovar (Amorphophallus variabilis Blume); Axoncom (Axonopus compressus (Sw.) P.Beauv.); Bioph (Biophytum sp); Biopsen (Biophytum sensitivum (L.) DC.); Boehniv (Boehmeria nivea (L.) Gaudich.); Boesro (Boesenbergia rotunda(L.) Mansf.) Centropu (Centrosema pubescens Benth.); Chromodor (Chromolaena odorata (L.) R.M.King \& H.Rob.); Coloes (Colocasia esculenta (L.) Schott); Commel (Commelina sp); Cosspir (Costus spiralis (Jacq.) Roscoe); Curcu (Curcuma sp); Curhey (Curcuma heyneana Valeton \& Zijp); Curlo (Curcuma longa L.); Cyapro (Cyathula prostrata (L.) Blume); Diosal (Dioscorea alata L.); Diospenta (Dioscorea pentaphylla L); Dioshis (Dioscorea hispida Dennst.); Elepsca (Elephantopus scaber L.); Eleptom (Elephantopus tomentosus L.); Emilson (Emilia sonchifolia (L.) DC. ex DC); Globmar (Globba marantina L); Gomp (Gomphostemma sp); Hypol (Hypoestes polythyrsa Miq.); Impat (Impatiens sp); Mararun (Maranta arundinacea L.); Mikcor (Mikania cordata (Burm.f.) B.L.Rob.); Mimopu (Mimosa pudica L); Murnud (Murdannia nudiflora (L.) Brenan); Oplis (Oplismenus sp); Opbur (Oplismenus burmanni (Retz.) P.Beauv.); Opcomp (Oplismenus compositus (L.) P.Beauv. ); Oxbar (Oxalis barrelieri L.); Pancrat (Pancratium sp); Peperpel (Peperomia pellucida (L.) Kunth); Sperneo (Spermacoce neohispida Govaerts); Spiganth (Spigelia anthelmia L); Syne (Synedrella sp); Synnodi (Synedrella nodiflora (L.) Gaertn.); Typtri (Typhonium trilobatum (L.) Schott); Urelo (Urena lobata L.); Zingzer (Zingiber zerumbet (L.) Roscoe ex Sm.). 


\section{ACKNOWLEDGEMENTS}

My sincere thanks go to Abdul Ghoni and Djafar (Purwodadi Botanic Garden, Indonesian Institute of Sciences, Pasuruan, Indonesia) for the assistance in the field.

\section{REFERENCES}

Akhalkatsi M, Arabuli G, Lorenz R. 2014. Orchids as indicator species of forest disturbances on limestone quarry in Georgia (South Caucasus). J Eur Orch 46 (1): 123-160.

Cleavitt NL, Berry EJ. Hautaniemi J, Fahey TJ. 2016. Life stages, demographic rates and leaf damage for the round-leaved orchids, Platanthera orbiculata (Pursh.) Lindley and P. macrophylla (Goldie) P.M. Brown in a northern hardwood forest, New Hampshire, USA Botany 95 (1): 61-71.

Coates F, Lunt ID, Tremblay RL. 2006. Effects of disturbance on population dynamics of the threatened orchid Prasophyllum correctum D.L. Jones and implications for grassland management in south-eastern Australia. Biol Conserv 129: 59-69

Comber JB. 1990. Orchids of Java. The Royal Botanic Gardens. Kew, Richmond, Surrey, UK

Comita LS, Uriarte M, Thompson J, Jonckheere I, Canham CD, Zimmerman JK. 2009. Abiotic and biotic drivers of seedling surviva in a hurricane-impacted tropical forest. J Ecol 97: 1346-1350.

Endels P, Adriaens D, Verheyen K, Hermy M. 2004. Population structure and adult plant performance of forest herbs in three contrasting habitats. Ecography 27 (2): 225-241.

Gale SW, Fischer GA, Cribb PJ, Fay MF. 2018. Orchid conservation: bridging the gap between science and practice. Bot J Linn Soc 186 425-434.

Harvey HJ. 1985. Population biology and the conservation of rare species In: White J (ed.). Studies on Plant Demography; A Festschrift for John L. Harper Academic Press, London.

Hegland SJ, Leeuwen MV, Oostermeijer JGB. 2001. Population structure of Salvia pratensis in relation to vegetation and management of Dutch dry floodplain grasslands. J Appl Ecol 38: 1277-1289.

IUCN/SSCOrchidSpecialistGroup. 1996. Orchids-Status Survey and Conservation Action Plan.IUCN, Gland Switzerland and Cambridge, UK.

Jacquemyn H, Brys R, Hermy M, Willems JH. 2005. Does nectar reward affect rarity and extinction probabilities of orchid species? An assessment using historical records from Belgium and the Netherlands. Biol Conserv 121: 257-263.

Jacquemyn H, Brys R, Vandepitte K, Honnay O, Roldain-Ruiz I, Wiegand T. 2007. A spatially explicit analysis of seedling recruitment in the terrestrial orchid Orchispurpurea. New Phytologist 176: 448-459.

Jacquemyn H, Rossum FV, Brys R, Endels P, Hermy M, Triest L, Blust GD. 2003. Effects of agricultural land use and fragmentation on genetics, demography and population persistence of the rare Primula vulgaris, and implications for conservation. Belg J Bot 136 (1): 5-22.

Janeckova P, Wotavova K, Delbauerova I, Jersakova J, Kindlmann P. 2006. Relative effects of management and environmental conditions on performance and survival of populations of a terrestrial orchid, Dactylorhiza majalis. Biol Conserv 129: 40-49.

Jersakova J, Malinova T. 2007. Spatial aspects of seed dispersal and seedling recruitment in orchids. New Phytologist 176: 237-241.

Kull T, Hutchings MJ. 2006. A comparative analysis of decline in the distribution ranges of orchid species in Estonia and the United Kingdom. Biol Conserv 129: 31-39.

Kusmana C. 1995. Teknik Pengukuran Keanekaragaman Tumbuhan. Pelatihan Teknik Pengukuran dan Monitoring Biodiversity di Hutan Tropika Indonesia. Jurusan Koservasi Sumber Daya Hutan Fakultas Kehutanan Institut Pertanian Bogor, Bogor. [indonesian]

Lin W. 2012. Comparative reproductive biology of a rare endemic orchid and its sympatric congeners in Southwestern China. [Thesis]. Florida International University. Miami, FL.

Lunt ID, 1994. Variation in flower production of nine grassland species with time since fire, and implications for grassland management and restoration. Pac Conserv Biol 1: 359-366.

Nicolè F, Brzosko E, Till-Bottraud I. 2005. Population viability analysis of Cypripedium calceolus in a protected area: longevity, stability and persistence. J Ecol 93 (4): 716-726.

Nurfadilah S. 2017. Population study of Peristylus goodyeroides (Orchidaceae) in five habitats and implications for its conservation. Biodiversitas 18 (3): 1084-1091.

Oostermeijer JGB, van Veer R, den Nijs JCM. 1994. Population structure of the rare long-lived perennial Gentiana pneumonanthe in relation to vegetation and management in the Netherlands. J Appl Ecol 31: 428438.

Rasmussen HN, Dixon KW, Jersakova J, Tesitelova T. 2015. Germination and seedling establishment in orchids: a complex of requirements. Ann Bot 1-12

Sletvold N, Øien DI, Moen A. 2010. Long-term influence of mowing on population dynamics in the rare orchid Dactylorhiza lapponica: The importance of recruitment and seed production. Biol Conserv 143: 747-755.

Sutomo, Hobbs RJ, Cramer VA. 2015. Plant community structure and composition in secondary succession following wildfire from Nuèes Ardentes of mount Merapi, Indonesia. Trop Plant Res 2 (3): 204-214.

Vogt-Schilb H, Munoz F, Richard F, Schatz B. 2015. Recent declines and range changes of orchids in Western Europe (France, Belgium and Luxembourg) Biol Conserv 190: 133-141

WCSP [World Checklist of Selected Plant Families]. 2017. Geodorum densiflorum (Lam.) Schltr. https://wcsp.science.kew.org/ [24 December 2018].

Whigham DF, Willems JH. 2003.Demographic studies and life-history strategies of temperate terrestrial orchids as a basis for conservation. In: Dixon KW, Kell SP, Barrett RL, Cribb PJ (eds.). Orchid Conservation. Natural History Publications, Kota Kinabalu, Sabah.

Wotavova K, Balounova Z, Kindlmann P. 2004. Factors affecting persistence of terrestrial orchids in wet meadows and implications for their conservation in a changing agricultural landscape. Biol Conserv 118: 271-279. 